\title{
OPTIMASI PERSEDIAAN BAHAN BAKAR M INYAK (BBM) PADA PERTAMINA UPms VII DEPOT DONGGALA MENGGUNAKAN METODE GOAL PROGRAMMING
}

\author{
Masita1, A. I. Jaya², dan Resnawati ${ }^{3}$ \\ 1,2,3 Program Studi Matematika Jurusan Matematika \\ Fakultas Matematika dan IImu Pengetahuan Alam Universitas Tadulako \\ Jalan Sukarno-Hatta Km. 9 Palu 94118, Indonesia \\ ${ }^{1}$ masitasybakka@gmail.com, 2jayaindraagus@gmail.com, 3r35n4w4t1@yahoo.com
}

\begin{abstract}
Pertamina Depot Donggala UPMS VII is one of the fuel distributors to some areas in Central Sulawesi. The demand of fuel oil (BBM) is continuously increasing, hence the information about fuel demand predictions is needed in order to optimization the fuel inventory. The purposes of this study the optimum of fuel inventory as well as the profit of it. This study used Goal Programming to optimize the supply of fuel oil of the Pertamina Depot Donggala UPMS VII. The results showed that, the optimal inventory for each type of fuel (premium, diesel, pertamax, and kerosene) and the monthly fuel refueling are presented in sequence as follows, 35 million liters by charging 7 times, 15 million liters by charging 3 time, 1.2 million liters by charging one time, and 1,200,000 liters by charging 1 times. The profit gained per liter has been the optimum fuel inventory as well as the profit of it with a previous profit targets where the target profit prior month of Rp.10.440.178.500 and from the callculation is found that the profit for one month is Rp.12.160.000.000.
\end{abstract}

Keywords : Fuel Oil, Goal Programming, Supplying.

\section{ABSTRAK}

Pertamina UPms VII Depot Donggala merupakan salah satu penyalur bahan bakar minyak ke beberapa daerah di Sulawesi Tengah. Bahan Bakar minyak (BBM) permintaannya terus menerus mengalami peningkatan, oleh karena itu dibutuhkan informasi mengenai prediksi kebutuhan BBM yang berguna dalam upaya pengoptimalan persediaan . Tujuan penelitian ini adalah untuk mendapatkan persediaan bahan bakar minyak yang optimal dan besarnya keuntungan yang dapat diperoleh. Penelitian ini menggunakan metode Goal Programming untuk mengoptimalkan persediaan bahan bakar minyak pada Pertamina Upms VII Depot Donggala. Dari hasil penelitian didapatkan persediaan optimal untuk masing-masing jenis BBM (premium, solar, pertamax, dan minyak tanah) dan banyaknya pengisian setiap bulan disajikan secara terurut sebagai berikut, 35.000 .000 liter dengan pengisian 7 kali, 15.000.000 liter dengan pengisian 3 kali, 1.200 .000 liter dengan pengisian 1 kali, dan 1.200 .000 liter dengan pengisian 1 kali. Keuntungan per bulan yang diperoleh telah dicapai sesuai dengan target keuntungan sebelumnya dimana target keuntungan per bulan sebelumnya sebesar Rp.10.628.600.000 dan hasil perhitungan keuntungan per bulan sebesar Rp. 12.160.000.000.

Kata Kunci : Bahan Bakar Minyak, Goal Programming, Persediaan. 


\section{PENDAHULUAN}

\subsection{Latar Belakang}

Bahan Bakar minyak (BBM) merupakan kebutuhan dasar dalam bidang industrimaupun transportasi yang semakin lama semakin meningkat permintaannya. Membagi wilayah distribusi menjadi beberapa region merupakan salah satu bagian strategi manajemen yang dilakukan untuk memudahkan distribusi bahan bakar hingga ke seluruh wilayah Indonesia. Pemasaran serta pendistribusian BBM berkaitan erat dengan seberapa besar kebutuhansetiap wilayah, dimana permintaan yang cenderung tidak konstan. Sehingga harus dilakukan proyeksi kebutuhan untuk beberapa bulan ke depan guna kepentingan perencanaan persediaan (Kusumaningrum, Dkk, 2013). Goal Programming adalah salah satu pemecahan masalahmult tujuan karena melalui variabel deviasinya, goal programming secara otomatis menangkap informasi tentang pencapaian relatif dari tujuan yang ada (Charles D dan Simson, 2002). Menurut Elikson D. (2013), Goal programming adalah bentuk khusus atau modifikasi darilinear programming. Goal programming ditujukan untuk mengatasi masalah dengan lebih dari satu tujuan. Tujuan-tujuan tersebut bisa saling berkaitan dengan tujuan lain, maka solusi terhadap satu tujuan menguntungkan tujuan yang lain.

Regresi sederhana adalah suatu pola hubungan yang merupakan fungsi dimanahanya terdapat satu variabel yang menentukan atau variabel bebas. Secara matematis, hubungan tersebut dapat dinotasikan sebagai $Y=f(X)$, dimana $Y$ adalah variabel yang diramalkan dan $X$ adalah variabel bebas (Makridakis, 1999). Pemeriksaan linearitas data deret waktu dapat menggunakan plot-plot dari titik persebaran data. Jika titik-titik nampak terletak sekitar garis lurus, maka trend dikatakan linear. Jika sebaliknya, titik-titik menjauhi garis lurus, maka trend tak linear. (sudjana, 2000).

Pertamina UPms VII Depot Donggala merupakan penyalur bahan bakar minyak ke seluruh daerah di Sulawesi tengah untuk memenuhi kebutuhan masyarakat. Penelitian ini bertujuan untuk mengoptimalkan peramalan penyaluran bahan bakar minyak untuk persedian tahun 2016 berdasarkan data pada tahun 2013-2015 dan menentukan besarnya keuntungan yang diperoleh Pertamina menggunakan metode Goal Programming.

\subsection{Rumusan Masalah}

Berdasarkan uraian latar belakang di atas maka rumusan masalah dalam penelitian ini adalah :

1. Bagaimana mengoptimalkan hasil proyeksi penyaluran bahan bakar minyak pada Pertamina UPms VII Depot Donggala.

2. Berapa keuntungan yang dapat diperoleh oleh pertamina per bulan dengan menggunakan metode Goal Programming. 


\subsection{Tujuan Penelitian}

Adapun tujuan dari penelitian ini adalah :

1. Mendapatkan bahan bakar minyak yang optimal dalam menyelesaikan masalah persedian.

2. Mendapatkan besarnya keuntungan per bulan yang ingin dicapai Pertamina UPms VII Depot Donggala.

\subsection{Manfaat Penelitian}

Manfaat yang diperoleh dari penelitian ini adalah memberikan informasi dan masukan bagi Pertamina UPms VII Depot Donggala untuk meningkatkan keakuratan dalam proyeksi kebutuhan dan mengoptimalkan model persediaan dalam upaya untuk meminimalisir persediaan serta mencegah terjadinya kelangkaan BBM.

\subsection{Batasan Masalah}

Adapun batasan-batasan permasalahan yang akan dibahas dalam penelitian ini agar pembahasan yang akan dibahas lebih terfokus yaitu sebagai berikut :

1. Penelitian hanya dilakukan pada bahan bakar minyak yang terdiri dari premium (gasoline), solar (automotive diese/ oil/ ADO), minyak tanah (kerosene) dan pertamax (motor gasoline).

2. Penelitian ini dilakukan menggunakan data penyaluran bahan bakar minyak dari tahun 2013-2015 di Pertamina UPms VII Depot Donggala.

\subsection{Asumsi Penelitian}

1. Setiap kali pengisian ulang BBM ketangki, tangki dalam keadaan kosong.

2. Harga BBM tidak berubah.

3. Perusahaan beroprasi dalam keadaan normal yaitu pada saat pemesanan dan pengiriman stok BBM ke depot tidak terjadi keterlambatan.

\section{METODE PENELITIAN}

Langkah-langkah yang dilakukan dalam penelitian ini yaitu :

1. Memulai penelitian

2. Studi literature

3. Pengambilan data

4. Uji linearitas

5. Proyeksi

6. Membangun model matematika dari hasil proyeksi

7. Menyelesaikan model matematis dengan metode Goal Programming

8. Menyimpulkan hasil penelitian

9. Selesai 


\section{HASIL DAN PEMBAHASAN}

\subsection{Pengambilan Data}

Data yang diperlukan dalam penelitian ini yaitu, kapasitas tangki, penyaluran bahan bakar minyak 2013-2015 dan keuntungan di Pertamina UPms VII Depot Donggala. Adapun data yang diambil dari pertamina UPms VII Depot Donggala sebagai berikut :

1. Kapasitas Gudang BBM

Tabel 1 : Kapasitas Gudang BBM.

\begin{tabular}{|l|c|}
\hline \multicolumn{1}{|c|}{ Jenis BBM } & Kapasitas Tangki (Kilo liter) \\
\hline Premium & 5000 \\
\hline Solar & 5000 \\
\hline Pertamax & 1200 \\
\hline Minyak Tanah & 1200 \\
\hline
\end{tabular}

2. Penyaluran bahan bakar minyak

Tabel 2 : Penyaluran bahan bakar minyak tahun 2013-2015.

\begin{tabular}{|c|c|c|c|c|c|c|c|c|c|c|c|}
\hline \multirow{2}{*}{ Tahun } & \multirow{2}{*}{ Bulan } & \multirow{2}{*}{$\begin{array}{l}\text { Indeks } \\
\text { waktu } \\
(X)\end{array}$} & \multirow{2}{*}{$X^{\wedge} 2$} & \multicolumn{2}{|c|}{$\begin{array}{l}\text { Premium } \\
\text { (kilo liter) }\end{array}$} & \multicolumn{2}{|c|}{$\begin{array}{c}\text { Solar } \\
\text { (kilo liter) }\end{array}$} & \multicolumn{2}{|c|}{$\begin{array}{l}\text { Pertamax } \\
\text { (kilo liter) }\end{array}$} & \multicolumn{2}{|c|}{$\begin{array}{l}\text { Minyak tanah } \\
\text { (kilo liter) }\end{array}$} \\
\hline & & & & Y & $X . Y$ & $\mathrm{Y}$ & $X . Y$ & $\mathrm{Y}$ & $X . Y$ & $\mathrm{Y}$ & X.Y \\
\hline \multirow{12}{*}{2013} & Januari & 1 & 1 & 27031 & 27031 & 10094 & 10094 & 234 & 234 & 1260 & 1260 \\
\hline & Februari & 2 & 4 & 24254 & 48508 & 11332 & 22664 & 305 & 610 & 1265 & 2530 \\
\hline & Maret & 3 & 9 & 23211 & 69633 & 12558 & 37674 & 256 & 768 & 1265 & 3795 \\
\hline & April & 4 & 16 & 26204 & 104816 & 11377 & 45508 & 329 & 1316 & 1265 & 5060 \\
\hline & Mei & 5 & 25 & 22262 & 111310 & 11429 & 57145 & 356 & 1780 & 1265 & 6325 \\
\hline & Juni & 6 & 36 & 22892 & 137352 & 10063 & 60378 & 322 & 1932 & 1275 & 7650 \\
\hline & Juli & 7 & 49 & 24266 & 169862 & 11496 & 80472 & 234 & 1638 & 1275 & 8925 \\
\hline & Agustus & 8 & 64 & 22327 & 178616 & 12747 & 101976 & 233 & 1864 & 1285 & 10280 \\
\hline & September & 9 & 81 & 28927 & 260343 & 11366 & 102294 & 232 & 2088 & 1285 & 11565 \\
\hline & Oktober & 10 & 100 & 24025 & 240250 & 9751 & 97510 & 223 & 2230 & 1233 & 12330 \\
\hline & November & 11 & 121 & 29222 & 321442 & 10500 & 115500 & 243 & 2673 & 1233 & 13563 \\
\hline & Desember & 12 & 144 & 25027 & 300324 & 11587 & 139044 & 322 & 3864 & 1233 & 14796 \\
\hline \multirow{12}{*}{2014} & Januari & 13 & 169 & 33273 & 432549 & 12026 & 156338 & 207 & 2691 & 1105 & 14365 \\
\hline & Februari & 14 & 196 & 28272 & 395808 & 12473 & 174622 & 322 & 4508 & 1100 & 15400 \\
\hline & Maret & 15 & 225 & 26267 & 394005 & 11316 & 169740 & 280 & 4200 & 1105 & 16575 \\
\hline & April & 16 & 256 & 24222 & 387552 & 12264 & 196224 & 302 & 4832 & 1105 & 17680 \\
\hline & Mei & 17 & 289 & 30227 & 513859 & 12464 & 211888 & 334 & 5678 & 1110 & 18870 \\
\hline & Juni & 18 & 324 & 30307 & 545526 & 11414 & 205452 & 405 & 7290 & 1120 & 20160 \\
\hline & Juli & 19 & 361 & 25022 & 475418 & 12746 & 242174 & 421 & 7999 & 1000 & 19000 \\
\hline & Agustus & 20 & 400 & 25444 & 508880 & 13300 & 266000 & 523 & 10460 & 1010 & 20200 \\
\hline & september & 21 & 441 & 30923 & 649383 & 11124 & 233604 & 433 & 9093 & 1025 & 21525 \\
\hline & Oktober & 22 & 484 & 35325 & 777150 & 11485 & 252670 & 233 & 5126 & 1105 & 24310 \\
\hline & november & 23 & 529 & 25043 & 575989 & 11362 & 261326 & 300 & 6900 & 1122 & 25806 \\
\hline & desember & 24 & 576 & 31089 & 746136 & 12193 & 292632 & 376 & 9024 & 1102 & 26448 \\
\hline \multirow{9}{*}{2015} & Januari & 25 & 625 & 45465 & 1136625 & 12254 & 306350 & 366 & 9150 & 1045 & 26125 \\
\hline & Februari & 26 & 676 & 31545 & 820170 & 13544 & 352144 & 355 & 9230 & 1050 & 27300 \\
\hline & Maret & 27 & 729 & 26336 & 711072 & 12576 & 339552 & 266 & 7182 & 1050 & 28350 \\
\hline & April & 28 & 784 & 30548 & 855344 & 11469 & 321132 & 387 & 10836 & 1050 & 29400 \\
\hline & Mei & 29 & 841 & 27236 & 789844 & 12556 & 364124 & 335 & 9715 & 1050 & 30450 \\
\hline & Juni & 30 & 900 & 31548 & 946440 & 12389 & 371670 & 425 & 12750 & 1070 & 32100 \\
\hline & Juli & 31 & 961 & 30232 & 937192 & 13357 & 414067 & 402 & 12462 & 1055 & 32705 \\
\hline & Agustus & 32 & 1024 & 25486 & 815552 & 12476 & 399232 & 565 & 18080 & 1065 & 34080 \\
\hline & september & 33 & 1089 & 36255 & 1196415 & 11307 & 373131 & 468 & 15444 & 825 & 27225 \\
\hline
\end{tabular}




\begin{tabular}{|c|c|c|c|c|c|c|c|c|c|c|}
\hline Oktober & 34 & 1156 & 36522 & 1241748 & 13618 & 463012 & 473 & 16082 & 440 & 14960 \\
\hline november & 35 & 1225 & 24952 & 873320 & 12408 & 434280 & 485 & 16975 & 440 & 15400 \\
\hline desember & 36 & 1296 & 27236 & 980496 & 13033 & 469188 & 558 & 20088 & 440 & 15840 \\
\hline
\end{tabular}

3. Keuntungan Perusahaan per liter

Tabel 3 : Keuntugan Perusahaan.

\begin{tabular}{|l|c|}
\hline \multicolumn{1}{|c|}{ Jenis BBM } & Keuntungan (Rp/liter) \\
\hline Premium & 200 \\
\hline Solar & 300 \\
\hline Pertamax & 350 \\
\hline Minyak Tanah & 200 \\
\hline
\end{tabular}

Sumber : (Pertamina UPms VII Depot Donggala).

\subsection{Uji Linearitas}

Penentuan metode regresi sederhana diperoleh melalui tahap pengujian yaitu uji linearitas data. Pengujian linearitas data penyaluran sebagai berikut:

a) Premium tahun 2013-2015

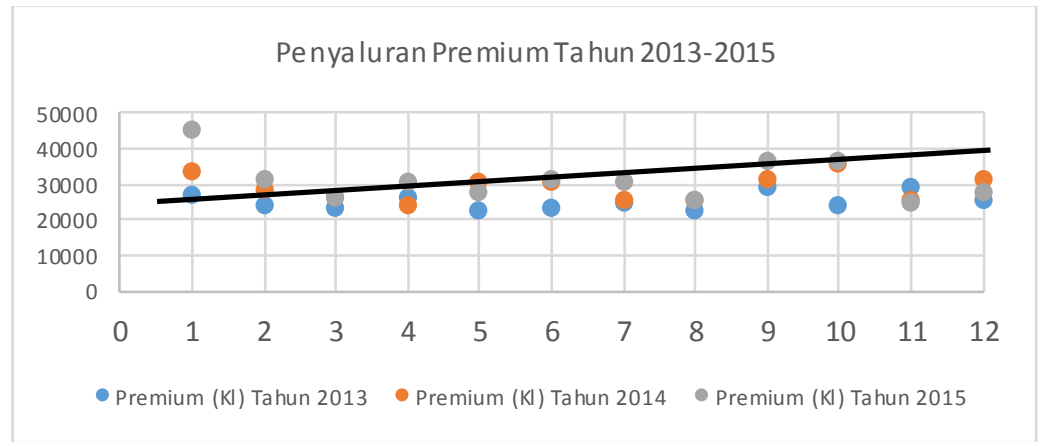

Gambar 1 : Plot data aktual penyaluran premium.

b) Solar tahun 2013-2015

Penyaluran solar tahun 2013-2015

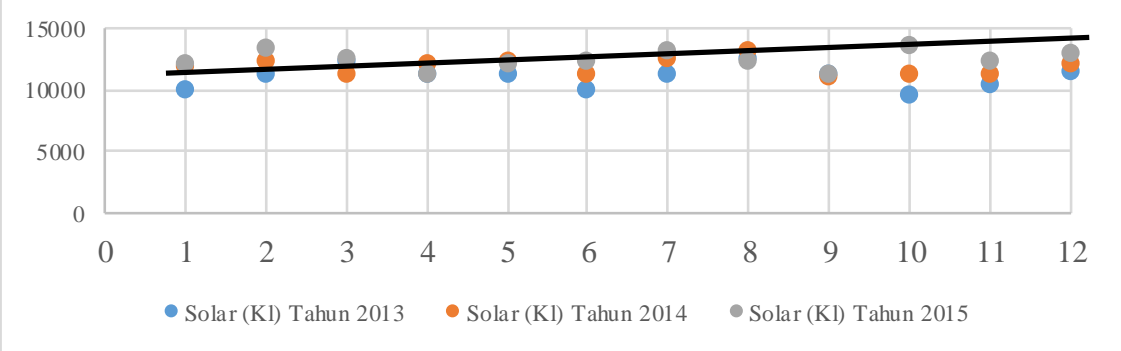

Gambar 2 : Plot data aktual penyaluran solar. 
c) Pertamax tahun 2013-2015

penyaluran pertamax tahun 2013-2015

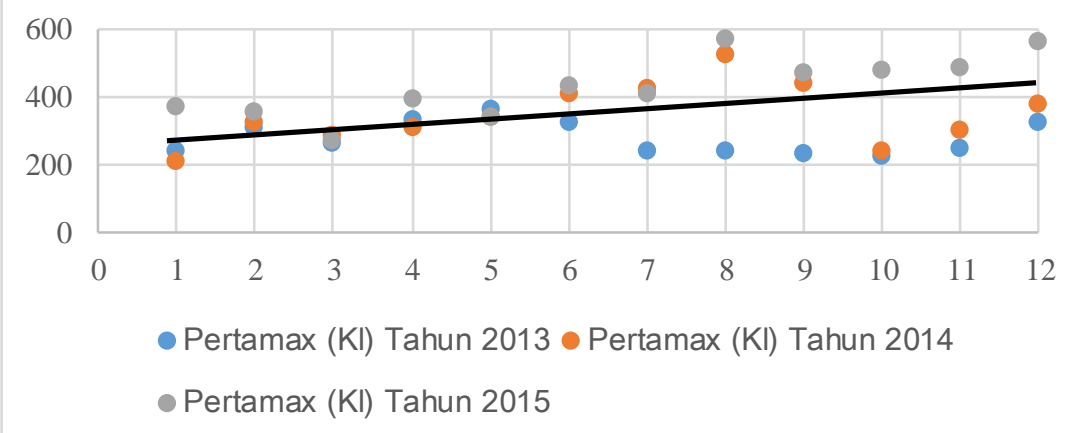

Gambar 3 : Plot data aktual penyaluran pertamax.

d) Minyak tanah tahun 2013-2015

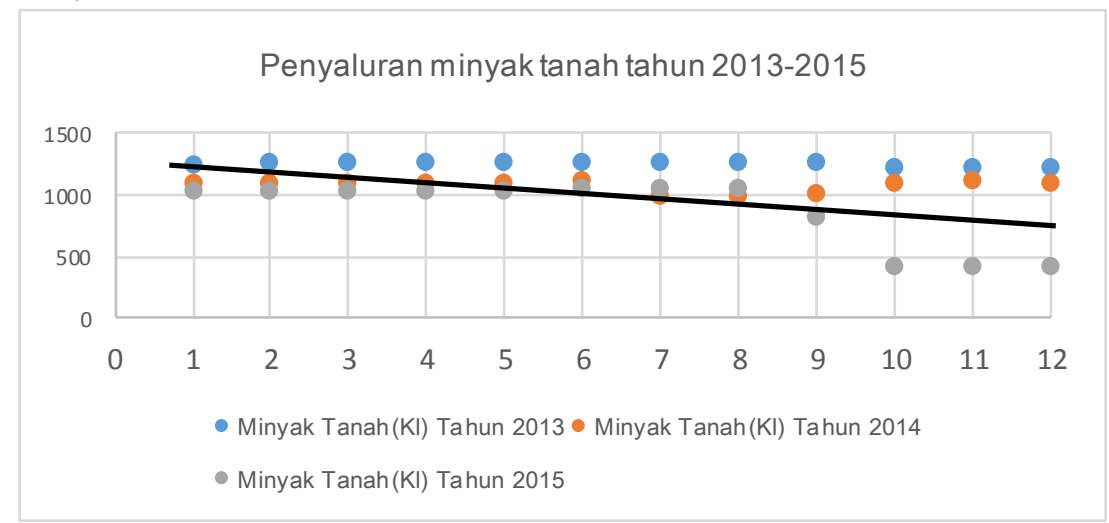

Gambar 4 : Plot data aktual penyaluran pertamax.

\subsection{Perhitungan Proyeksi Menggunakan Metode Regresi Sederhana}

\subsubsection{Premium}

Rumus mencari nilai proyeksi menggunakan metode regresi sederhana adalah sebagai berikut:

$\hat{Y}=a+b X$

Dimana :

$\hat{Y}=$ taksiran nilai trend

untuk nilai a dan $\mathrm{b}$ dari hasil perhitungan sebagai berikut :

$b=\frac{N \sum X Y-\sum X \sum Y}{N \sum X^{2}-\left(\sum X\right)^{2}}=\frac{(35 \times 18211439)-(630 \times 972958)}{(35 \times 14910)-(630)^{2}}=\frac{637400365-612963540}{521850-396900}=195,57$

$a=\bar{Y}-b \bar{X}=\frac{972958}{35}-195,5 \frac{630}{35}=\frac{972958-123165}{35}=24279,7$

Maka $: \hat{Y}=a+b X=24279,7+195,5(X)$

*)Hasil proyeksi untuk masing-masing bahan bakar minyak dibulatkan. 
Misalkan $\hat{Y}$ adalah nilai ham piran terhadap nilai sejati $Y$, maka selisih $\varepsilon=Y-\hat{Y}$ disebut galat (Renaldi Munir, 2006). Adapun rumus mencari galat relatif adalah :

$\varepsilon_{R}=\frac{\varepsilon}{Y}$

Dan rata-rata galat relatif adalah :

$\overline{\varepsilon_{R}}=\frac{\sum_{i=1}^{n} \varepsilon_{R}}{n} \times 100 \%$

Tabel 4 : Penyelesaian Proyeksi Penyaluran Premium 2016

\begin{tabular}{|c|c|c|c|c|c|c|}
\hline Tahun & Bulan & Data aktual $(\mathrm{Y})$ & Proyeksi & $\varepsilon$ & $|\varepsilon|$ & $\varepsilon_{R}$ \\
\hline \multirow{12}{*}{2013} & Januari & 27031 & 24528 & 2503 & 2503 & 0,09 \\
\hline & Februari & 24254 & 24743 & -489 & 489 & 0,02 \\
\hline & Maret & 23211 & 24958 & -1747 & 1747 & 0,08 \\
\hline & April & 26204 & 25173 & 1031 & 1031 & 0,04 \\
\hline & Mei & 22262 & 25388 & -3126 & 3126 & 0,14 \\
\hline & Juni & 22892 & 25603 & -2711 & 2711 & 0,12 \\
\hline & Juli & 24266 & 25817 & -1551 & 1551 & 0,06 \\
\hline & Agustus & 22327 & 26032 & -3705 & 3705 & 0,17 \\
\hline & September & 28927 & 26247 & 2680 & 2680 & 0,09 \\
\hline & Oktober & 24025 & 26462 & -2437 & 2437 & 0,10 \\
\hline & November & 29222 & 26677 & 2545 & 2545 & 0,09 \\
\hline & Desember & 25027 & 26892 & -1865 & 1865 & 0,07 \\
\hline \multirow{12}{*}{2014} & Januari & 33273 & 27107 & 6167 & 6167 & 0,19 \\
\hline & Februari & 28272 & 27322 & 950 & 950 & 0,03 \\
\hline & Maret & 26267 & 27537 & -1270 & 1270 & 0,05 \\
\hline & April & 24222 & 27752 & -3530 & 3530 & 0,15 \\
\hline & Mei & 30227 & 27967 & 2260 & 2260 & 0,07 \\
\hline & Juni & 30307 & 28182 & 2125 & 2125 & 0,07 \\
\hline & Juli & 25022 & 28397 & -3375 & 3375 & 0,13 \\
\hline & Agustus & 25444 & 28612 & -3168 & 3168 & 0,12 \\
\hline & september & 30923 & 28827 & 2096 & 2096 & 0,07 \\
\hline & Oktober & 35325 & 29042 & 6283 & 6283 & 0,18 \\
\hline & november & 25043 & 29257 & -4214 & 4214 & 0,17 \\
\hline & desember & 31089 & 29472 & 1617 & 1617 & 0,05 \\
\hline \multirow{13}{*}{2015} & Januari & 45465 & 29687 & 15778 & 15778 & 0,35 \\
\hline & Februari & 31545 & 29902 & 1643 & 1643 & 0,05 \\
\hline & Maret & 26336 & 30117 & -3781 & 3781 & 0,14 \\
\hline & April & 30548 & 30332 & 216 & 216 & 0,01 \\
\hline & Mei & 27236 & 30547 & -3311 & 3311 & 0,12 \\
\hline & Juni & 31548 & 30762 & 786 & 786 & 0,02 \\
\hline & Juli & 30232 & 30977 & -745 & 745 & 0,02 \\
\hline & Agustus & 25486 & 31192 & -5706 & 5706 & 0,22 \\
\hline & september & 36255 & 31407 & 4849 & 4849 & 0,13 \\
\hline & Oktober & 36522 & 31622 & 4900 & 4900 & 0,13 \\
\hline & november & 24952 & 31836 & -6884 & 6884 & 0,28 \\
\hline & desember & 27236 & 32051 & -4815 & 4815 & 0,18 \\
\hline & & 1018423 & & & & 4,02 \\
\hline
\end{tabular}


Nilai rata-rata galat relatifnya menggunakan persamaan (3) Yaitu :

$\overline{\varepsilon_{R}}=\frac{\sum_{i=1}^{n} \varepsilon_{R}}{n} \times 100 \%=\frac{4,02}{36} \times 100 \%=11,1 \%$

\subsubsection{Solar}

Gunakan metode Regresi sederhana dengan rumus persamaan (1) :

untuk nilai a dan $\mathrm{b}$ dari hasil perhitungan sebagai berikut :

$b=\frac{N \sum X Y-\sum X \sum Y}{N \sum X^{2}-\left(\sum X\right)^{2}}=\frac{(36 \times 8140811)-(666 \times 429454)}{(36 \times 16206)-(666)^{2}}=\frac{293069196-286016364}{583416-443556}=50,427$

$a=\bar{Y}-b \bar{X}=\frac{429454}{36}-50,427 \frac{666}{36}=\frac{429454-33586,38}{36}=\frac{395869,086}{36}=10996,363$

Maka: $\hat{Y}=a+b X=10996,363+50,427(X)$

Tabel 5 : Penyelesaian proyeksi penyaluran solar 2016

\begin{tabular}{|c|c|c|c|c|c|c|}
\hline Tahun & Bulan & Data aktual $(\mathrm{Y})$ & Proyeksi & $\varepsilon$ & $|\varepsilon|$ & $\varepsilon_{R}$ \\
\hline \multirow{12}{*}{2013} & Januari & 10094 & 11047 & -953 & 953 & 0,09 \\
\hline & Februari & 11332 & 11097 & 235 & 235 & 0,02 \\
\hline & Maret & 12558 & 11148 & 1410 & 1410 & 0,11 \\
\hline & April & 11377 & 11198 & 179 & 179 & 0,02 \\
\hline & Mei & 11429 & 11249 & 181 & 181 & 0,02 \\
\hline & Juni & 10063 & 11299 & -1236 & 1236 & 0,12 \\
\hline & Juli & 11496 & 11349 & 147 & 147 & 0,01 \\
\hline & Agustus & 12747 & 11400 & 1347 & 1347 & 0,11 \\
\hline & September & 11366 & 11450 & -84 & 84 & 0,01 \\
\hline & Oktober & 9751 & 11501 & -1750 & 1750 & 0,18 \\
\hline & November & 10500 & 11551 & -1051 & 1051 & 0,10 \\
\hline & Desember & 11587 & 11602 & -15 & 15 & 0,00 \\
\hline \multirow{12}{*}{2014} & Januari & 12026 & 11652 & 374 & 374 & 0,03 \\
\hline & Februari & 12473 & 11702 & 771 & 771 & 0,06 \\
\hline & Maret & 11316 & 11753 & -437 & 437 & 0,04 \\
\hline & April & 12264 & 11803 & 461 & 461 & 0,04 \\
\hline & Mei & 12464 & 11854 & 610 & 610 & 0,05 \\
\hline & Juni & 11414 & 11904 & -490 & 490 & 0,04 \\
\hline & Juli & 12746 & 11955 & 792 & 792 & 0,06 \\
\hline & Agustus & 13300 & 12005 & 1295 & 1295 & 0,10 \\
\hline & september & 11124 & 12055 & -931 & 931 & 0,08 \\
\hline & Oktober & 11485 & 12106 & -621 & 621 & 0,05 \\
\hline & november & 11362 & 12156 & -794 & 794 & 0,07 \\
\hline & desember & 12193 & 12207 & -14 & 14 & 0,00 \\
\hline \multirow{8}{*}{2015} & Januari & 12254 & 12257 & -3 & 3 & 0,00 \\
\hline & Februari & 13544 & 12308 & 1237 & 1237 & 0,09 \\
\hline & Maret & 12576 & 12358 & 218 & 218 & 0,02 \\
\hline & May & 11469 & 12408 & -939 & 939 & 0,08 \\
\hline & Mei & 12556 & 12459 & -203 & 203 & 0,02 \\
\hline & Juni & 12389 & 12509 & -120 & 120 & 0,01 \\
\hline & Juli & 13357 & 12560 & 797 & 797 & 0,06 \\
\hline & Agustus & 12476 & 12610 & -134 & 134 & 0,01 \\
\hline
\end{tabular}




\begin{tabular}{|c|c|r|r|r|r|r|}
\hline september & 11307 & 12661 & -1353 & 1353 & 0,12 \\
\cline { 2 - 6 } & Oktober & 13618 & 12711 & 907 & 907 & 0,07 \\
\cline { 2 - 7 } & november & 12408 & 12761 & -353 & 353 & 0,03 \\
\cline { 2 - 7 } & desember & 13033 & 12812 & 221 & 221 & 0,02 \\
\hline & Total & 429454 & & & & 1,94 \\
\hline
\end{tabular}

rata-rata galat relatifnya menggunakan persamaan (3) Yaitu :

$\overline{\varepsilon_{R}}=\frac{\sum_{i=1}^{n} \varepsilon_{R}}{n} \times 100 \%=\frac{1,94}{36} \times 100 \%=5,4 \%$

\subsubsection{Pertamax}

Gunakan metode Regresi sederhana dengan rumus persamaan (1) :

untuk nilai a dan b dari hasil perhitungan sebagai berikut:

$b=\frac{N \sum X Y-\sum X \sum Y}{N \sum X^{2}-\left(\sum X\right)^{2}}=\frac{(36 \times 256792)-(666 \times 12510)}{(36 \times 16206)-(666)^{2}}=\frac{9244512-8331660}{583416-443556}=\frac{912852}{139860}$

$=6,526$

$a=\bar{Y}-b \bar{X}=\frac{12510}{36}-6,526 \frac{666}{36}=\frac{12510-4346,914}{36}=\frac{8163,085}{36}=226,752$

Maka : $\hat{Y}=a+b X=226,752+6,526(X)$

Tabel 6 : Penyelesaian proyeksi penyaluran pertamax 2016

\begin{tabular}{|c|c|c|c|c|c|c|}
\hline Tahun & Bulan & $\begin{array}{c}\text { Data aktual } \\
\text { (Y) }\end{array}$ & Proyeksi & $\varepsilon$ & $|\varepsilon|$ & $\varepsilon_{R}$ \\
\hline \multirow{12}{*}{2013} & Januari & 234 & 233 & 0,72 & 0,72 & 0,00 \\
\hline & Februari & 305 & 240 & 65,19 & 65,19 & 0,21 \\
\hline & Maret & 256 & 246 & 9,67 & 9,67 & 0,04 \\
\hline & April & 329 & 253 & 76,14 & 76,14 & 0,23 \\
\hline & Mei & 356 & 259 & 96,61 & 96,61 & 0,27 \\
\hline & Juni & 322 & 266 & 56,09 & 56,09 & 0,17 \\
\hline & Juli & 234 & 272 & $-38,44$ & 38,44 & 0,16 \\
\hline & Agustus & 233 & 279 & $-45,97$ & 45,97 & 0,20 \\
\hline & September & 232 & 286 & $-53,49$ & 53,49 & 0,23 \\
\hline & Oktober & 223 & 292 & $-69,02$ & 69,02 & 0,31 \\
\hline & November & 243 & 299 & $-55,55$ & 55,55 & 0,23 \\
\hline & Desember & 322 & 305 & 16,92 & 16,92 & 0,05 \\
\hline \multirow{13}{*}{2014} & Januari & 207 & 312 & $-104,6$ & 104,6 & 0,51 \\
\hline & Februari & 322 & 318 & 3,87 & 3,87 & 0,01 \\
\hline & Maret & 280 & 325 & $-44,66$ & 44,66 & 0,16 \\
\hline & May & 302 & 331 & $-29,18$ & 29,18 & 0,10 \\
\hline & Mei & 334 & 338 & $-3,71$ & 3,71 & 0,01 \\
\hline & Juni & 405 & 344 & 60,76 & 60,76 & 0,15 \\
\hline & Juli & 421 & 351 & 70,24 & 70,24 & 0,17 \\
\hline & Agustus & 523 & 357 & 165,71 & 165,71 & 0,32 \\
\hline & september & 433 & 364 & 69,18 & 69,18 & 0,16 \\
\hline & Oktober & 233 & 370 & $-137,34$ & 137,34 & 0,59 \\
\hline & november & 300 & 377 & $-76,87$ & 76,87 & 0,26 \\
\hline & desember & 376 & 383 & $-7,4$ & 7,4 & 0,02 \\
\hline & Januari & 366 & 390 & $-23,92$ & 23,92 & 0,07 \\
\hline
\end{tabular}




\begin{tabular}{|l|l|c|c|c|c|c|}
\cline { 2 - 7 } 2015 & Februari & 355 & 397 & $-41,45$ & 41,45 & 0,12 \\
\cline { 2 - 7 } & Maret & 266 & 403 & $-136,98$ & 136,98 & 0,51 \\
\cline { 2 - 7 } & May & 387 & 411 & $-22,51$ & 22,51 & 0,06 \\
\cline { 2 - 7 } & Mei & 335 & 416 & $-81,03$ & 81,03 & 0,24 \\
\cline { 2 - 7 } & Juni & 425 & 423 & 2,44 & 2,44 & 0,01 \\
\cline { 2 - 7 } & Juli & 402 & 429 & $-27,09$ & 27,09 & 0,07 \\
\cline { 2 - 7 } & Agustus & 565 & 436 & 129,39 & 129,39 & 0,23 \\
\cline { 2 - 7 } & september & 468 & 442 & 25,59 & 25,59 & 0,05 \\
\cline { 2 - 7 } & Oktober & 473 & 449 & 24,33 & 24,33 & 0,05 \\
\cline { 2 - 7 } & november & 485 & 455 & 29,81 & 29,81 & 0,06 \\
\cline { 2 - 7 } & desember & 558 & 462 & 96,28 & 96,28 & 0,17 \\
\hline & Total & 12510 & & & & 6,20 \\
\hline
\end{tabular}

Nilai rata-rata galat relatifnya menggunakan persamaan (3) Yaitu :

$\overline{\varepsilon_{R}}=\frac{\sum_{i=1}^{n} \varepsilon_{R}}{n} \times 100 \%=\frac{6,20}{36} \times 100 \%=17,2 \%$

\subsubsection{Minyak Tanah}

Gunakan metode Regresi sederhana dengan rumus persamaan (1) :

untuk nilai a dan $\mathrm{b}$ dari hasil perhitungan sebagai berikut:

$b=\frac{N \sum X Y-\sum X \sum Y}{N \sum X^{2}-\left(\sum X\right)^{2}}=\frac{(36 \times 652353)-(666 \times 38728)}{(36 \times 16206)-(666)^{2}}=\frac{23484708-25792848}{583416-443556}=-16,503$

$a=\bar{Y}-b \bar{X}=\frac{38728}{36}-(-16,503) \frac{666}{36}=\frac{38728+10990,998}{36}=\frac{49718,998}{36}=1381,083$

Maka $: \hat{Y}=a+b X=1381,083-16,503(X)$

Tabel 7 : Penyelesaian proyeksi penyaluran minyak tanah 2016

\begin{tabular}{|c|c|c|c|c|c|c|}
\hline Tahun & Bulan & $\begin{array}{c}\text { Data aktual } \\
(\mathrm{Y})\end{array}$ & Proyeksi & $\varepsilon$ & $|\varepsilon|$ & $\varepsilon_{R}$ \\
\hline \multirow{12}{*}{2013} & Januari & 1260 & 1365 & -105 & 105 & 0,08 \\
\hline & Februari & 1265 & 1348 & -83 & 83 & 0,07 \\
\hline & Maret & 1265 & 1332 & -67 & 67 & 0,05 \\
\hline & April & 1265 & 1315 & -50 & 50 & 0,04 \\
\hline & Mei & 1265 & 1299 & -34 & 34 & 0,03 \\
\hline & Juni & 1275 & 1282 & -7 & 7 & 0,01 \\
\hline & Juli & 1275 & 1266 & 9 & 9 & 0,01 \\
\hline & Agustus & 1285 & 1249 & 36 & 36 & 0,03 \\
\hline & September & 1285 & 1233 & 52 & 52 & 0,04 \\
\hline & Oktober & 1233 & 1216 & 17 & 17 & 0,01 \\
\hline & November & 1233 & 1200 & 34 & 34 & 0,03 \\
\hline & Desember & 1233 & 1183 & 50 & 50 & 0,04 \\
\hline \multirow{7}{*}{2014} & Januari & 1105 & 1167 & -62 & 62 & 0,06 \\
\hline & Februari & 1100 & 1150 & -50 & 50 & 0,05 \\
\hline & Maret & 1105 & 1134 & -29 & 29 & 0,03 \\
\hline & April & 1105 & 1117 & -12 & 12 & 0,01 \\
\hline & Mei & 1110 & 1101 & 10 & 10 & 0,01 \\
\hline & Juni & 1120 & 1084 & 36 & 36 & 0,03 \\
\hline & Juli & 1000 & 1068 & -68 & 68 & 0,07 \\
\hline
\end{tabular}




\begin{tabular}{|c|c|c|c|c|c|c|}
\hline & Agustus & 1010 & 1051 & -41 & 41 & 0,04 \\
\hline & september & 1025 & 1035 & -10 & 10 & 0,01 \\
\hline & Oktober & 1105 & 1018 & 87 & 87 & 0,08 \\
\hline & november & 1122 & 1002 & 121 & 121 & 0,11 \\
\hline & desember & 1102 & 985 & 117 & 117 & 0,11 \\
\hline \multirow{13}{*}{2015} & Januari & 1045 & 969 & 77 & 77 & 0,07 \\
\hline & Februari & 1050 & 952 & 98 & 98 & 0,09 \\
\hline & Maret & 1050 & 936 & 115 & 115 & 0,11 \\
\hline & April & 1050 & 919 & 131 & 131 & 0,12 \\
\hline & Mei & 1050 & 903 & 148 & 148 & 0,14 \\
\hline & Juni & 1070 & 886 & 184 & 184 & 0,17 \\
\hline & Juli & 1055 & 870 & 186 & 186 & 0,18 \\
\hline & Agustus & 1065 & 853 & 212 & 212 & 0,2 \\
\hline & september & 825 & 837 & -12 & 12 & 0,01 \\
\hline & Oktober & 440 & 820 & -380 & 380 & 0,86 \\
\hline & november & 440 & 804 & -364 & 364 & 0,83 \\
\hline & desember & 440 & 787 & -347 & 347 & 0,79 \\
\hline & Total & 38728 & & & & 4,6 \\
\hline
\end{tabular}

Nilai rata-rata galat relatifnya menggunakan persamaan (3) Yaitu :

$\overline{\varepsilon_{R}}=\frac{\sum_{i=1}^{n} \varepsilon_{R}}{n} \times 100 \%=\frac{4,6}{36} \times 100 \%=12,7 \%$

Hasil proyeksi penyaluran bahan bakar minyak untuk tahun 2016 menggunakan metode Regresi sederhana adalah sebagai berikut :

Tabel 8 : Hasil Proyeksi BBM Tahun 2016

\begin{tabular}{|l|c|c|c|c|}
\hline Bulan & $\begin{array}{c}\text { Premium } \\
\text { (Kilo liter) }\end{array}$ & $\begin{array}{c}\text { Solar } \\
\text { (Kilo liter) }\end{array}$ & $\begin{array}{c}\text { Pertamax } \\
\text { (Kilo liter) }\end{array}$ & $\begin{array}{c}\text { Minyak Tanah } \\
\text { (Kilo liter) }\end{array}$ \\
\hline Januari & 32266 & 12862 & 468 & 771 \\
\hline Februari & 32481 & 12913 & 475 & 754 \\
\hline Maret & 32696 & 12963 & 481 & 738 \\
\hline April & 32911 & 130134 & 488 & 721 \\
\hline Mei & 33126 & 13064 & 494 & 705 \\
\hline Juni & 33341 & 13114 & 501 & 688 \\
\hline Juli & 33556 & 13165 & 507 & 672 \\
\hline Agustus & 33771 & 13215 & 514 & 655 \\
\hline September & 33986 & 13266 & 521 & 638 \\
\hline Oktober & 34201 & 13316 & 527 & 622 \\
\hline November & 34416 & 13367 & 534 & 605 \\
\hline Desember & 34631 & 13417 & 540 & 589 \\
\hline
\end{tabular}

Metode yang memberikan hasil proyeksi secara tepat belum tentu tepat untuk memproyeksi data yang lain. Maka dari itu diperlukan Untuk menguji akurasi hasil proyeksi di atas digunakan metode analisa galat. Dari hasil perhitungan analisa galat didapatkan nilai dari rata-rata galat relatif untuk masing-masing jenis bahan bakar 
minyak yaitu untuk premium nilai rata-rata galat relatif sebesar $11,1 \%$, solar nilai ratarata galat relatif sebesar $5,4 \%$, pertamax nilai rata-rata galat relatif sebesar $17,2 \%$ dan minyak tanah nilai rata-rata galat relatif sebesar $12,7 \%$.

\subsection{Penentuan Variabel Keputusan}

$X_{1}=$ Banyaknya pengisian premium perbulan

$X_{2}=$ Banyaknya pengisian solar perbulan

$X_{3}=$ Banyaknya pengisian pertamax perbulan

$X_{4}=$ Banyaknya pengisian minyak tanah perbulan

\subsubsection{Formulasi model matematik penyaluran BBM}

Sasaran yang ingin dicapai dalam formulasi ini adalah memaksimalkan persedian bahan bakar minyak, maka deviasi negatif (kekurangan persedian bahan bakar minyak) diusahakan nol. Model Goal Programming untuk mengoptimalkan persediaan bahan bakar minyak adalah :

5.000.000 $X_{1}+d_{1}^{-}-d_{1}^{+}=32.266 .000$ liter

$5.000 .000 X_{2}+d_{2}^{-}-d_{2}^{+}=12.862 .000$ liter

$1.200 .000 X_{3}+d_{3}^{-}-d_{3}^{+}=468.000$ liter

1.200.000 $X_{4}+d_{4}^{-}-d_{4}^{+}=771.000$ liter

1.4.2. Formulasi model matematik target keuntungan

Setelah memformulasikan model penyaluran bahan bakar minyak kita harus memformulasikan target keuntungan diamana setiap perusahaan mengharapkansuatu keuntungan yang maksimal. Maka dari itu kita harus menetapkan keuntunganyangingin dicapai berada diatas perkiraan. Model goal programming untuk memaksimalkan keuntungan bahan bakar minyak adalah:

$200 X_{5}+300 X_{6}+350 X_{7}+200 X_{8}+d_{5}^{-}-d_{5}^{+}=10.628 .600 .000$.

1.4.3. Menentukan prioritas utama dan fungsi tujuan

Adapun prioritas utama dan urutannya, yaitu :

Prioritas $1\left(P_{1}\right)$ : Tersedianya jenis bahan bakar premium sesuai dengan tingkat persediaan aman.

Prioritas $2\left(P_{2}\right)$ : Tersedianya jenis bahan bakar solar sesuai dengan tingkat persediaan aman.

Prioritas $3\left(P_{3}\right)$ : Tersedianya jenis bahan bakar pertamax sesuai dengan tingkat persediaan aman.

Prioritas $4\left(P_{4}\right)$ : Tersedianya jenis bahan bakar minyak tanah sesuai dengan tingkat persediaan aman.

Prioritas $5\left(P_{5}\right)$ : Target Keuntungan rupiah yang ingin dicapai.

1.4.4. Fungsi tujuan dan kendala tujuan

Setelah menentukan prioritas dan urutannya, fungsi tujuan yang terbentuk adalah : 
Minimumkan $Z=P_{1}\left(d_{1}^{+}+d_{1}^{-}\right)+P_{2}\left(d_{2}^{+}+d_{2}^{-}\right)+P_{3}\left(d_{3}^{+}+d_{3}^{-}\right)+P_{4}\left(d_{4}^{+}+d_{4}^{-}\right)+$ $P_{5}\left(d_{5}^{+}+d_{5}^{-}\right)$

Kendala Tujuan :

5.000.000 $X_{1}+d_{1}^{-}-d_{1}^{+}=32.266 .000$ liter

$5.000 .000 X_{2}+d_{2}^{-}-d_{2}^{+}=12.862 .000$ liter

$1.200 .000 X_{3}+d_{3}^{-}-d_{3}^{+}=468.000$ liter

$1.200 .000 X_{4}+d_{4}^{-}-d_{4}^{+}=771.000$ liter

$200 X_{5}+300 X_{6}+350 X_{7}+200 X_{8}+d_{5}^{-}-d_{5}^{+}=10.628 .600 .000$

Kendala Non Negatif:

$X_{1}, X_{2}, X_{3}, X_{4}, d_{1}^{-}, d_{2}^{-}, d_{3}^{-}, d_{4}^{-}, d_{5}^{-}, d_{1}^{+}, d_{2}^{+}, d_{3}^{+}, d_{4}^{+}, d_{5}^{-} \geq 0$

\subsubsection{Penyelesaian goal programming menggunakan aplikasi QM for Windows}

Penyelesaian metode Goal Programming dapat dilakukan dengan menggunakan aplikasi QM for Windows. Aplikasi ini dapat menyelesaikan persoalan dengan cepat dan lebih akurat. Penyelesaiannya sesuai dengan hasil yang dicari dan jumlah kendala yang ada. Masukan nilai-nilai kendala tujuan pada tabel sesuai dengan kotak-kotak yang ada seperti berikut :

\begin{tabular}{|l|r|r|r|r|r|r|r|r|r|r|}
\hline & & & & & & & & & & \\
\hline & Wt(d+) & Prty(d+) & Wt(d-) & Prty(d-) & X1 & $X 2$ & $X 3$ & $X 4$ & RHS \\
\hline GoaVCnstrnt 1 & 1 & 1 & 1 & 1 & 5000000 & 0 & 0 & 0 & $=$ \\
\hline GoaVCnstrnt 2 & 1 & 2 & 1 & 2 & 0 & 5000000 & 0 & 0 & $=$ \\
\hline GoaVCnstrnt 3 & 1 & 3 & 1 & 3 & 0 & 0 & 1200000 & 0 & $=$ & 42266000 \\
\hline GoaVCnstrnt 4 & 1 & 4 & 1 & 4 & 0 & 0 & 0 & 1200000 & $=$ & 768000 \\
\hline GoaVCnstrnt 5 & 1 & 5 & 1 & 5 & 200 & 300 & 350 & 200 & $=$ & 10628600000 \\
\hline
\end{tabular}

Gambar 5 : Tampilan kendala tujuan yang diisi pada kotak yang bersesuaian

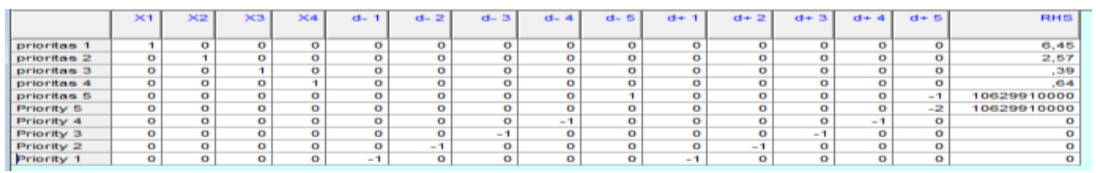

Gambar 6 : Tampilan hasil kendala tujuan

\section{KESIMPULAN}

Berdasarkan pembahasan yang telah dipaparkan diatas, dapat diambil kesimpulan bahwa hasil:

1. Proyeksi penyaluran bahan bakar minyak untuk tahun 2016 menggunakan metode adalah sebagai berikut:

Tabel 9 : Hasil Proyeksi BBM Tahun 2016.

\begin{tabular}{|l|c|c|c|c|}
\hline \multicolumn{1}{|c|}{ Bulan } & $\begin{array}{c}\text { Premium } \\
\text { (Kilo liter) }\end{array}$ & $\begin{array}{c}\text { Solar } \\
\text { (Kilo liter) }\end{array}$ & $\begin{array}{c}\text { Pertamax } \\
\text { (Kilo liter) }\end{array}$ & $\begin{array}{c}\text { Minyak Tanah } \\
\text { (Kilo liter) }\end{array}$ \\
\hline Januari & 32266 & 12862 & 468 & 771 \\
\hline Februari & 32481 & 12913 & 475 & 754 \\
\hline Maret & 32696 & 12963 & 481 & 738 \\
\hline April & 32911 & 130134 & 488 & 721 \\
\hline Mei & 33126 & 13064 & 494 & 705 \\
\hline Juni & 33341 & 13114 & 501 & 688 \\
\hline Juli & 33556 & 13165 & 507 & 672 \\
\hline
\end{tabular}




\begin{tabular}{|l|l|l|l|l|} 
Agustus & 33771 & 13215 & 514 & 655 \\
\hline September & 33986 & 13266 & 521 & 638 \\
\hline Oktober & 34201 & 13316 & 527 & 622 \\
\hline November & 34416 & 13367 & 534 & 605 \\
\hline Desember & 34631 & 13417 & 540 & 589 \\
\hline
\end{tabular}

2. Persediaan optimal premium per bulan sebesar 35.000.000liter dengan banyaknya pengisian 7 kali sesuai dengan kapasitas tangki sebesar 5.000.000 liter, persediaan optimal solar per bulan sebesar 15.000 .000 liter dengan banyaknya pengisian 3 kali sesuai dengan kapasitas tangki sebesar 5.000.000 liter, persediaan optimal pertamax per bulan sebesar 1.200.000liter dengan banyaknya pengisian 1 kali sesuai dengan kapasitas tangki sebesar 1.200 .000 liter, persediaan optimal pada bahan bakar minyak minyak tanah per bulan sebesar 1.200.000liter dengan banyaknya pengisian 1 kali sesuai dengan kapasitas tangki sebesar 1.200 .000 liter.

3. Keuntungan yang dapat dicapai per bulan untuk tahun 2016 sebesar Rp. 12.160.000.000. Didapatkan nilai rupiah dimana target keuntungan per bulan yang ditetapkan melebihi dari target sebesar Rp.1.531.400.000.

\section{DAFTAR PUSTAKA}

[1]. Charles, D. dan Simpson, T., Goal Programming Aplication In Multi discriplinary design Optimization. 2002.

[2]. Damanik, E., Penerapan metode goal programming untuk mengoptimalkan produksi teh(studi kasus PT. Perkebunan Nusantara IV-Pabrik Teh Bah Butong), Fakultas MIPA Universitas Sumatera Utara, 2013, Medan.

[3]. Kusumaningrum, Oktavianis,, Dkk., Peramalan kebutuhan bahan bakar premium di depot Ampenan dengan metode hibrida arima-neural network untuk optimasi persedian, Fakultas FMIPA Institut Teknologi Sepuluh November (ITS), 2013, Surabaya.

[4]. Makridakis, S., Dkk., Metode Dan Aplikasi Peramalan. Terjemahan Untung Sus Andriyantodan Abdul Basith, Erlangga, 1999, Jakarta.

[5]. Renaldi Munir., Metode Numerik. Penerbit Informatika, 2006, Bandung.

[6]. Sudjana., Metode Statistika: PT. Gramedia Pustaka Utama, 2000, Bandung. 